\title{
Examining the Levels of Forgiveness and Psychological Resilience of Teacher Candidates
}

\author{
Sermet Toktas \\ Correspondence: Sermet Toktas, School of Physical Education and Sports, Bayburt University, Turkey. \\ Received: March 6, 2019 \\ Accepted: March 19, 2019 Online Published: March 24, 2019 \\ doi:10.11114/jets.v7i4.4122 \\ URL: https://doi.org/10.11114/jets.v7i4.4122
}

\begin{abstract}
The aim of this study is to evaluate the forgiveness and psychological resilience of the pre-service teachers in the department of physical education and sports in sports education and psychology according to different variables. The study group consisted of 479 university students studying in Kahramanmaras, Gaziantep, Burdur, Denizli and Mersin during the 2017-2018 academic year. Gender in the personal information form, the team or individual sports and the personal information form prepared for the department were used as data collection tools of the study. The short psychological resilience scale developed by Smith et al. (2008) and adapted to Turkish by Dogan (2015) was used to determine the psychological stability levels of the study group. The Affinity Scale Developed by Berry et al. (2005); adapted to Turkish by Akin, Gediksiz and Akin (2012) was used in the study to evaluate the forgiveness of the research group. The data were analyzed by using SPSS Statistics 22.0 package program, Pearson Product Moment Correlation, ANOVA, Tukey multiple comparison and t test method. As a result of the research, a positive and low correlation was found between psychological resilience and forgiveness. Between gender and forgiveness, girls' scores were found more meaningful and higher than those of males. No significant meaningful correlation between psychological resilience and forgiveness level of the students engaged in team and individual sports was found. When the participants were examined in terms of the department they studied, no relationship with psychological stability was found. When the participants were examined in terms of the department they studied, the scores of the students of the coaching department were found to be higher in the forgiveness than those of the physical education and sports teacher.
\end{abstract}

Keywords: psychological strength, forgiveness, student, sports

\section{Introduction}

When the fields of psychology development in social sciences were examined, it is noticed that many studies investigating the socio-psychological aspects of youth were carried. The universities perceived as the highest point in education life, academic staff of universities, teenagers taking education are seen as important are as for researchers (Yesilyaprak, 2002). The ability of an individual to return to normal or expected experiences against undesired experiences and to cope with problems is defined as psychological stability (Block and Kremen, 1996). While the teacher candidates try to adapt to the university environment and the new social environment in these sensitive times, they need to take control of their own lives as they move away from the environment and the family environment in addition to their academic examination period stresses and competitive environment. In addition to this, they try to deal with many stressors such as expectations from their future, evaluating their communication with the opposite sex and social friends. In addition to being an environment where pre-service teachers are socialized, university life is a period in which stress factor affects students. Some students are able to quickly recover without being overwhelmed by adverse living conditions, undesirable experiences, stress and difficult life conditions, and even survive these stressful processes by strengthening (Ogulmus, 2001). In spite of such negative experiences, the responses of each individual who are unlike each other will not be similar. While some individuals know how to live their lives by leaving behind indescribable painful lives, this process cannot be overcome easily for others. In these periods, the psychological stability of a person plays a role (Eryilmaz, 2012). There are expressions that describe the individuals who are able to overcome these processes which can stretch but not break and are recovered quickly and urgently. In English, the term RESILIENT is said to be related to the situation of people getting over the troubled periods lightly. Besides, "resilience" "resiliency" expressions are also used to express those who are strong in character, resilient-durable, can be quickly recovered, can cope with difficulties, have resistance, can be stretched and have a solid structure (Bezmez, Blakney, Brown, 1999). In this study, the definition of resilience is expressed as psychological resistance. In literature reviews, 
with the increase of forgiveness, there has been a decrease in the emotional state such as anxiety, depression, anger and guilt which affect the social-life negatively (Capan and Aricioglu, 2014). They associate the psychological deficiencies of the athletes with the low motivation capacities or if any, problems or illnesses they can assert. The athletes with strong motivation level have high psychological levels (Mumcu, Acet, Kusan, Zambak, Koc 2017). People who are psychologically strong can continue their lives more easily and adapt to the current situation despite the risk factors caused by the traumatic lives (Guloglu and Karairmak, 2010). In the light of these findings, it is possible to consider the psychological strength and forgiveness as factors that enable fast adaptation to social life. As a result of this research, it was aimed to draw attention to this relationship and to contribute to the field by determining the relationship between psychological stability and forgiveness.

Psychological resilience was first discussed conceptually in America. Definitions such as happiness, tolerance, forgiveness, optimism, authenticity, psychological satisfaction, gratitude, well-being or well-being, life satisfaction, hope, psychological well-being and well-being, and sense of responsibility have been included in the literature as definitions integrated with positive psychology. While targeting one's potential, strengths and positive characteristics, it has contributed positively to psychology, positive psychology and psychological counseling as a very conspicuous understanding in the millenium age we live in (Seligman and Csikszentmihalyi, 2000). It has always aroused interest in the efforts to forget the effect of negative experiences in individuals' lives, and to build constructive and sound dialogues with others after difficult processes. The fact that individuals try to adapt to unreliable situations has been the priority of the researches carried out about psychological stability (Karairmak, 2006). Although the psychological strength was first discussed in the USA in terms of definition, the study of Rutter (1985) in Great Britain in the last quarter of the 20th century indicated that it was important in the development of the term psychological. It is understood that some individuals are able to stand firm against negative situations and try to find new alternative options and effectively solve problems. The most decisive factor in fitting this harmony is the psychologically sound and powerful condition that enables the individual to act effectively and is fluid in a process (Werner, 1995; Pietrzak, Johnson, Goldstein, Malley and Soutwick, 2009). The beliefs of individuals in terms of stress, adverse life conditions and that they will get stronger as long as they can deal with these processes bring the term psychological the term into an examinationable state, and scientists have accelerated research on these terms (Terzi, 2005).

According to some researchers, psychological stability is expressed as to overcome of disaster-like difficulties or changes in a very good way (Wagnild and Young 1993). Different scientists have expressed psychological well-being as the ability to adapt to the causes of serious health problems, occupational and financial problems, family-related or social difficulties, traumatic, and threatening severe stress (Tusaire and Dyer 2004). Psychological resilience is a general definition investigating how children deal with stress and how they are healthy from a traumatic process (Murphy and Hampton, 1988). Psychological resilience is the mobile periods in which individuals exhibit adaptations against difficult and difficult traumas. Being exposed to risk and yet there are constructive consequences are the two dimensions of psychological soundness, and the ability to overcome the difficulties that the person is exposed to is due to his psychological soundness (Luthar and Cichetti 2000). When the characteristics of individuals with high levels of psychological robustness are considered, it is possible to express the people who are psychologically strong as the people who can turn the challenging downturn processes into life, even in the event of crisis, who can nominate themselves to their jobs, any negative process they encounter can keep their level of anxiety at the low level, who do not lose their control (Sahin, 2014). Psychologically sound individuals are defined as individuals who have a good intelligence, do not communicate with their problematic peers and avoid the guilt in adolescent periods (Gurgan, 2006).

If the literature search related to the definition of forgiveness was made, it would be seen that many researchers have tried to express this expression from different aspects due to the lack of a consensus about this concept.

There is not a consensus definition regarding the definition of forgiveness (Berry et al., 2005). It is possible to say that forgiveness is a personality trait that poses positive results for individuals and social relationships (Berry et al. 2005). The concept of forgiveness and forgiveness traces back to quiet old times (Droll, 1984).

In the past, many thinkers and writers touch upon the greatness of forgiveness and try to shape literature by stating that it is too much cost and cost to get revenge (Droll, 1984). Forgiveness is perceived as a fundamental virtue in Hindu culture (Rye et al., 2000).

According to the Turkish Language Association, forgiveness is described as "forgiving a crime, a defect or a mistake". Grant and forgiveness mean "to abandon their complaints and to end their anger" in the old English (Droll, 1984). According to Enright and Gassin (1992), the negative effects of grant or forgiveness are expressed as feeling more positive in knowing and behaving, empathizing, psychological balance, respect, showing pity and reconciliation and the process of displacement. Hargrave and Sells (1997) emphasize the nature of the relationship while seeing forgiveness as the recovery of lost trust. Worthington (1997) also says that forgiveness is the state of man's avoiding to irritability, 
negative feelings, revenge or retaliation against the one who upset him. McCullough, Pargament, and Thoresen (2001) refer to forgiveness as a process of transformation through an internal constructive transformation by renouncing the feeling of anger and revenge towards the offender.

Considering these definitions, the positive relationship between forgiveness and psychological strength makes life easier for people. Our research is aimed to determine the relationship between psychological resilience and forgiveness and both shed light on and contribute knowledge to the field.

\section{Method}

\subsection{Research Model}

This study, which investigated the relationship between the psychological strength and forgiveness of the students in the department of Psychology and Sports and the psychological strengths, the psychological strengths and the forgiving characteristics of the students in terms of different factors, was conducted with the relational screening model. The relational screening model is a study system that aims to determine whether there is a change between multiple factors or the level of this relationship, at the same time does not give a cause-effect relationship, but provides some clues in this direction, and provides useful results by estimating the situation in another variable (Karasar, 2010).

\subsection{Population and Sample}

The study group of the study consisted of university students who were educated in the sports sciences faculty in Kahramanmaras, Gaziantep, Burdur, Denizli and Mersin in the 2017-2018 academic year. The sample is composed of 479 students determined by random selection method. Of the participants, 135 were female and 344 were male.

\subsection{Data Collection Tools}

\subsubsection{Demographic Information Form}

In this study, a demographic data form was prepared to determine the demographic data which was supposed to be related to the psychological strength and forgiveness of the students of the sports faculty taking psychology and sports training. In this information form, the answer to questions about gender, department of education, and sports category are sought.

\subsubsection{Forgiveness Scale}

The Forgiveness Scale which was develoed by Berry et al. (2005), and adapted the Turkish version by Akin, Gediksiz and Akin (2012) was used to determine the level of forgiveness of the participants in the research. The scale of forgiveness is one-dimensional and consists of 10 items. The 1st, 3rd, 7th and 8th items of the scale are reverse materials. The items are scored as Strongly Disagree (1), Disagree (2), Undecided (3), Agree (4), and Strongly Agree (5). The high scores obtained in the scoring key refer to high forgiveness, low scores to low forgiveness. The Trait Forgivingness Scale is a subscale of the 15-item scale of Berry and Worthington (2001). In the four studies conducted for the validity and reliability of the scale, Cronbach alpha internal consistency coefficients were determined as 80, .78, .79 and 74. Duzeltilen madde toplam korelasyonlari yapilan tum calismalarda 30 ile 63 arasinda bulunmustur. When the scales were applied to the participants after 8 weeks and the test-retest reliability was examined, the results were also found statistically significant ( $\mathrm{r}(60) 5.78$, po.001).

\subsubsection{The Brief Resilience Scale (BRS)}

The Brief Resilience Scale (BRS), which was develoed by Smith et al. (2005), and adapted the Turkish version by Dogan (2012) was used to measure the psychological stability of the individuals in the research. BRS is a 5-likert type self-report format measurement tool consisting of 6 items and. The items are scored respectively as Not Appropriate at All (1), Not Appropriate (2), Slightly Appropriate (3), Appropriate (4), Fully Appropriate (5). The 2., 4., and 6. items of the scale are coded in reverse direction. In the scoring table, it can be stated that the high scores obtained after reversing these substances indicate high psychological strength, and less scores indicate low psychological strength. The validity and reliability studies of the scale were administered in four different sample groups. The first two groups were university students, while the other two groups consisted of heart and fibromyalgia patients. As a result of the analysis, a single factor structure was found for four different sample groups, representing $61 \%, 57 \%$ and $67 \%$ of the total variance, respectively. According to BRS items, measurements were determined between .63 and .79 as a result of factor loads. The .83 internal consistency coefficient of the scale and the test-retest reliability coefficient also showed that the CPSI was reliable. In order to determine the criterion-related validity of the scale, the Oxford Happiness Scale-Short Form (OHS-SH) (2011), Ego Stability Scale (ESS) (Karairmak, 2007) and Connor-Davidson Psychological Stability Scale (CDPSS) (2003) were applied. When the results were examined, it was seen that there was an association between BRS and OHS-SH $(r=, 40 \mathrm{p}<, 001)$, ESS $(r=, 61 \mathrm{p}<, 001)$ and CDPSS $(r=66 \mathrm{p}<.001)$. According to these data, it can be said that BRS has a sufficient level of validity. 


\subsection{Data Collection}

The study was conducted by gathering data of 479 university students who were educated in Sports Sciences Faculty in 2017-2018 Academic Year in Kahramanmaras, Gaziantep, Burdur, Denizli ve Mersin cities. The sample group was constituted of 479 university students determined by random method. A participant may complete the data collection materials provided to him / her in about 5-7 minutes. The participants were informed about the purpose and importance of the research. The participants were informed that the most appropriate answers should be given to the scales given to them, and not to share their credentials on the scales.

\subsection{Data Analysis}

The data obtained from 479 participants were analyzed with SPSS Statistics 22.0 package program. Before the research questions were answered, the normal distribution of the scores of forgiveness and psychological resilience at the level of all participating students was examined. Pearson Moments Multiplication Correlation Coefficient was used to test whether there was a significant correlation between the levels of psychological resilience and forgiveness of the participants in sports and psychology education. Independent sample t-test was used to determine whether the levels of psychological solidity and forgiveness differed according to gender, educational departments, sports category of the participants who took separate and different sports and psychology education from each other. While T test was applied, related $t$ values were noted by considering Levene test results. One-way analysis of variance (ANOVA) was used to determine whether the level of forgiveness and psychological resilience of the students taking psychology and sports education had changed according to the programs they received. Tukey multiple comparison method was used to determine the cause of difference in cases where statistically significant changes occurred.

\section{Results}

Table 1. Correlation Coefficient Table for Psychological Strength and Forgiveness Levels of Students

\begin{tabular}{|c|c|c|c|c|c|c|c|}
\hline \multirow{2}{*}{\multicolumn{2}{|c|}{ Variable }} & \multicolumn{4}{|c|}{ Forgiveness } & \multirow{2}{*}{\multicolumn{2}{|c|}{$\mathrm{N}$}} \\
\hline & & \multicolumn{2}{|l|}{$R$} & \multicolumn{2}{|c|}{$P$} & & \\
\hline \multicolumn{2}{|c|}{ Psychological Robustness } & .161 & & \multicolumn{2}{|c|}{.001} & \multicolumn{2}{|c|}{479} \\
\hline \multicolumn{8}{|c|}{$\begin{array}{l}\text { Discription: Pearson Product Moment Correlation coefficient was given in order to find out whether there was a } \\
\text { significant relationship between the psychological resilience and forgiveness of university students attending sports and } \\
\text { psychology education group. The correlation coefficient for the findings is shown in Table } 1 \text {. Table } 1 \text { shows that there is } \\
\text { a positively low correlation between the psychological resilience and forgiveness of the students receiving sports and } \\
\text { psychology education }(\mathrm{r}=.17, \mathrm{p}<.01) \text {. }\end{array}$} \\
\hline \multicolumn{8}{|c|}{$\begin{array}{l}\text { Table 2. T Test Table Related to Psychological Resilience and Forgiveness Levels of Students According to Their } \\
\text { Genders }\end{array}$} \\
\hline Variable & Gender & $\mathrm{N}$ & $X$ & Ss & $T$ & $S d$ & $P$ \\
\hline \multirow{2}{*}{$\begin{array}{l}\text { Psychological } \\
\text { Robustness }\end{array}$} & Female & 135 & 19.17 & 4.16 & \multirow[b]{2}{*}{1.24} & \multirow[b]{2}{*}{427} & \multirow[b]{2}{*}{.12} \\
\hline & Male & 344 & 19.57 & 4.22 & & & \\
\hline \multirow{2}{*}{ Forgiveness } & Female & 135 & 32.52 & 5.41 & \multirow{2}{*}{2.12} & \multirow{2}{*}{427} & \multirow{2}{*}{.03} \\
\hline & Male & 344 & 31.29 & 5.22 & & & \\
\hline
\end{tabular}

Discription: Table 2 shows the averages and standard deviations of university students studying sports and psychology for their psychological resilience in terms of gender. When we look at Table 2, psychological resilience in terms of gender is not statistically significant $(\mathrm{t} 0.05: 427=1.24, \mathrm{p}>.05$. Looking at the results, there are similar psychological resemblances between male and female students who are educated in sports and psychology. The averages and standard deviations for the level of forgiveness in terms of the gender of university students studying sports and psychology are indicated. When we look at Table 2, we can see that there is a statistically significant difference in forgiveness levels in terms of gender ( $\mathrm{t} 0.05: 427=2.12, \mathrm{p}<.05)$. The average point of forgiveness of female students who were educated in sports and psychology $(X=32.52$, ss $=5.41)$ was found to be significantly higher than that of male students who were educated in sports and psychology $(X=31.29$, ss $=5.22)$. According to these results, it can be said that female students who are educated in sports and psychology have significantly higher level of forgiveness than male university students. 
Table 3. T Test Table Related to Psychological Strengths and Forginess Levels in terms of Team Sports and Individual Sports

\begin{tabular}{|c|c|c|c|c|c|c|c|}
\hline Variable & Branch & $\mathrm{N}$ & $\mathrm{X}$ & Ss & $T$ & $S d$ & $P$ \\
\hline \multirow{2}{*}{$\begin{array}{l}\text { Psychological } \\
\text { Robustness }\end{array}$} & Individual & 197 & 18.02 & 4.17 & \multirow{2}{*}{1.22} & \multirow{2}{*}{441} & \multirow{2}{*}{.27} \\
\hline & Team & 282 & 18.97 & 4.38 & & & \\
\hline \multirow{2}{*}{ Forgiveness } & Individual & 197 & 32.84 & 5.03 & \multirow{2}{*}{1.54} & \multirow{2}{*}{441} & \multirow{2}{*}{.16} \\
\hline & Team & 282 & 33.66 & 5.34 & & & \\
\hline
\end{tabular}

Discription: Table 3 shows the mean and standard deviations of the university students studying sports and psychology for the level of psychological stability according to team sports and individual sports. When we look at Table 3, it was concluded that psychological strength levels did not show a statistically significant difference between team sports and individual sports ( $\mathrm{t} 0.05: 441=1.33, \mathrm{p}>.05)$.

Table 3 presents the averages and standard deviations of university students studying sports and psychology for the level of forgiveness according to team sports and individual sports. When we look at Table 3, it was concluded that the level of forgiveness shows no statistically significant difference between team sports and individual sports $(\mathrm{t} 0.05: 441=$ $1.54, \mathrm{p}>.05)$.

Table 4. Students Descriptive Statistics Related to Psychological Strengths and Forgiveness Levels

\begin{tabular}{|c|c|c|c|c|}
\hline Variable & Department & $\mathrm{N}$ & $\mathrm{X}$ & Ss \\
\hline \multirow{3}{*}{$\begin{array}{l}\text { Psychological } \\
\text { Robustness }\end{array}$} & Coaching & 123 & 19.17 & 4.21 \\
\hline & Physical Education and Sports Teaching & 194 & 19.47 & 4.27 \\
\hline & Sports Management & 162 & 16.68 & 4.02 \\
\hline \multirow{3}{*}{ Forgiveness } & Coaching & 123 & 34.62 & 5.81 \\
\hline & Physical Education and Sports Teaching & 194 & 32.71 & 4.96 \\
\hline & Sports Management & 162 & 32.66 & 5.45 \\
\hline
\end{tabular}

Discription: Table 4 shows the averages and standard deviations for the psychological resilience level of the students studying sports and psychology with different programs. The most points average in psychological robustness level belongs to the students of physical education and sports teaching department. Then, the students who study in the coaching department have a mean score in the second row, while the lowest mean score is for the students studying in the sports management department.

Table 4 shows the averages and standard deviations for the level of forgiveness of the students studying sports and psychology with different programs. The most points average in forgiveness level belongs to the students of coaching department. Then, the students who study in physical education and sports teaching department have a mean score in the second row, while the lowest mean score is for the students studying in the sports management department. Table 4 shows the ANOVA results whether there is a significant difference between these averages.

Table 5. Table of Variance Analysis Related to Psychological Resilience and Forgiveness Levels for Students in the Department They Study

\begin{tabular}{llccccc}
\hline Variable & Source of Variance & $\begin{array}{c}\text { Sum of } \\
\text { squares }\end{array}$ & Sd & $\begin{array}{c}\text { Mean } \\
\text { squares }\end{array}$ & F & $P$ \\
\hline $\begin{array}{l}\text { Psychological } \\
\text { Robustness }\end{array}$ & Between Groups & 40.89 & 3 & 21.1 & \multirow{2}{*}{1.230} & .243 \\
\cline { 2 - 5 } Forgiveness & In-group & 7005.008 & 419 & 17.2 & & \multirow{2}{*}{5.123} \\
\cline { 2 - 5 } & Between Groups & 311.422 & 3 & 157.2 & .005 \\
\hline
\end{tabular}

Discription: Table 5 shows the differences in the mean scores for psychological resilience levels of the students who take sports and psychology education in different programs. According to these findings, it is understood that there is no statistically significant difference between the psychological resilience mean scores of the students whose programs are 
different $(\mathrm{F} 2-419=1.23, \mathrm{p}>.05)$. According to these results, it is seen that the psychological resilience scores of the students who take sports and psychology education in the departments of physical education and sports, coaching and sports management do not differ significantly from each other.

Table 5 shows the differences in the mean scores for psychological forgiveness levels of the students who take sports and psychology education in different programs. According to these findings, it is understood that there is no statistically significant difference between the forgiveness mean scores of the students whose programs are different $(\mathrm{F} 2-419=5.123, \mathrm{p}<.01)$. As a result of the Tukey multiple comparison test conducted to determine the origin of this difference, it can be said that the difference is caused by the averages of forgiveness of the students studying in coaching. According to these results, it can be said that the students in the coaching department have higher levels of forgiveness than the students studying in physical education and sports education and sports management.

\section{Discussion}

When the results of the study were examined, it was determined that there was a low positive positive correlation between psychological resilience and forgiveness. Significant and positive correlation between psychological robustness and forgiveness characteristics is similar to the literature on this subject. Significant and positive correlation between psychological robustness and forgiveness characteristics is similar to the literature on this subject. In the study on the effect of forgiving therapies aimed at women suffering from abuse of alcohol by spouses, women who regularly participate in forgiveness therapies were found to have high levels of psychological stability (Hee Kyung and Mihyounguyun 2014). The complete realization of the virtue of forgiveness is stated to be related to the level of psychological stability of the individual (McCullough et al., 2009). The fact that forgiveness has a significant and positive relationship with psychological well-being is consistent with the literature on this issue. According to the findings of Sheffield (2003), forgiveness is associated with better psychological well-being. In a study by Bas, Aydin, Sebin (2018) named "The Investigation of Violence Physical Education Teachers Exposed and Strategies for coping with stress after violence", female teachers' positive reinterpretation and development, focusing on the problem and revealing emotions, use of social and emotional support were found higher than male teachers. In addition, it was found out that female teachers focused more on the problems, tried to solve the problems more logically, and told the problems to their environment and get and support from them, while the men did not see the problems, ignored the problems seriously and gave themselves to other duties. In the study by Aydin, and Bas (2018) called "The Effect of Levels of Resistance to Stress on the Quality of Life of Individuals going to Sports Centers", the way men and women approach events and situations; they tend to evaluate problems more calmly and realistically according to the sub-dimension of optimistic approach, self-confidence sub-dimension, their lives planned, active, logical and conscious, and in the submissive approach, instead of solving the problems they face in their lives, they blame themselves, find themselves as powerless, see themselves as a source of problems and feel helpless with a fatalistic approach and look for solutions in different dimensions were identified. Psychological stability levels of university students were examined in terms of gender, which is one of the demographic variables of the study. Psychological resilience scores of male and female students were analyzed by t-test method. According to the findings, it was seen that there was no significant difference between male and female students in terms of psychological resilience levels of the students. Toprak (2014) found that psychological resilience of adolescents did not differ according to gender as a result of a study conducted (Toprak, 2014). As a result of his research, Turgut (2015) found that adolescents had a significant difference in their psychological resilience score according to their gender, and that the mean score of girls was significantly higher than the mean score of boys (Turgut, 2015). According to the findings obtained from the study, it does not support the findings of Turgut's study while it is in parallel with the findings obtained from Toprak's study.

When we look at Table 2, there was a statistically significant difference in the level of forgiveness in terms of gender. It can be said that female students studying sports and psychology have a significantly higher level of forgiveness than male students. In the study conducted by Orathinkal, Vansteenwegen and Burggraeve (2008) with 735 participants, forgiveness and demographic variables were compared and it was found that women were more forgiving than men.

When considired in terms of team sports and individual sports, it was concluded that psychological stability levels did not show a statistically significant difference. When considered terms of team sports and individual sports, it was concluded that the level of forgiveness did not show a statistically significant difference. Bayraktaroglu (2014) did not find any differences between the psychological stability levels of individuals according to their individual and team sporting situations.

The most points average in psychological robustness level belongs to the students of physical education and sports teaching department. Then, the students who study in the coaching department have a mean score in the second row, while the lowest mean score is for the students studying in the sports management department. According to these findings, it is understood that there is no statistically significant difference between the psychological stability mean 
scores of the students whose programs are different (Eryilmaz, 2012). In the study which examined the psychological stability of the students studying in the Faculty of Education, Faculty of Arts and Sciences and the Faculty of Economics and Administrative Sciences, there was no significant difference in the psychological stability of the students according to the faculties they study at (Bora, 2018). The scores of the sports high school students on the scale of entrepreneurship competence were examined in terms of the variable of entrepreneurship included in the curriculum of sports high schools as an elective course. According to the results, it was found that students who have an elective course have a significantly higher score than the other students. From this point of view, it is thought that putting psychological resilience and forgiveness lessons into the curriculum as compulsory will have positive reflections on students.

The most points average in forgiveness level belongs to the students of coaching department. Then, the students who study in physical education and sports teaching department have a mean score in the second row, while the lowest mean score is for the students studying in the sports management department. According to these findings, it is seen that there is a statistically significant difference between the average of forgiveness points of the students whose programs are different. In the literature, there are researches that support this research. Kaya (2015) found that the average of forgiveness of students studying in the Faculty of Theology and Literature was higher than the Faculty of Economics and Administrative Sciences.

\section{Conclusion and Recommendations}

When the results of the study were examined, it was determined that there was a low positive positive correlation between psychological resilience and forgiveness. According to the findings, it was seen that there was no significant difference between male and female students in terms of their psychological stability levels. There was a statistically significant difference in the level of forgiveness in terms of gender. In terms of team sports and individual sports, it was concluded that there was no statistically significant difference between the levels of psychological resilience and forgiveness. The most points average in psychological resilience level belongs to the students of physical education and sports teaching department. Then, students studying in the coaching department come, and the lowest one belongs to the students of the department of sports management. The highest average point of forgiveness belongs to the students of the coaching department. Then, students studying in physical education and sports education come, and the lowest one belongs to the students of the department of sports management.

\subsection{Recommendations}

1. It is concluded that there is a positive relationship between psychological robustness and forgiveness. Our study was conducted to university students by using relational screening method. It will be more useful to study the future studies with relational screening model with different groups and large sample groups and to perform the study experimentally in order to reveal the functionality of the study.

2. Psychological counselors and psychologists are required to increase the awareness of the society about psychological soundness, the necessity and benefits of the forgiveness process. Seminars and meetings can be held that forgiveness is a virtue. Researchers may be encouraged to contribute to sports psychology literature

3. It is stated that the task of the researchers who are doing psychological strength and forgiveness is informing the society (Masten, 2014). It would be beneficial for families and schools to participate in the seminars on these studies.

4. It can be suggested that the researchers studying on this issue can make studies about which variables can be protective in the axis of the risks.

5. Given the positive relationship of forgiveness with psychological well-being, programs that encourage forgiveness in psychological counseling practices can be structured and implemented.

6. It can be thought that good planning of the time allocated to sports, which is an important part of the training and the environments that are necessary for individuals to do sports can be prepared by institutions and organizations.

7. Due to the potential benefits that will be provided by forgiveness, from the initial stages of all educational institutions, the promotion of the themes that promote forgiveness and reflect the importance and benefits of the children will be beneficial for the establishment of this feature.

\section{References}

American Psychological Association. (1972). Ethical standards of psychologists. Washington, DC: American Psychological Association.

Aydin, E., \& Bas, M. (2018). Spor Merkezlerine Devam Eden Bireylerin Strese Karsi Koyabilme Duzeylerinin Yasam Kalitesine Etkisi. Uluslararasi 2. Spor Arastirmalari Kongresi, 156-162. (Tam Metin Bildiri/Sozlu Sunum) (Yayin No:4554249). 
Bas, M., Aydin, E., \& Sebin, K. (2018). Beden Egitimi Ogretmenlerinin Maruz Kaldiklari Siddet ve Siddet Sonrasi Ortaya Cikan Stresle Basa Cikma Stratejilerinin Incelenmesi. Uluslararasi 2. Akademik Spor Arastirmalari Kongresi, 399-407. Tam Metin Bildiri. Sozlu Sunum. Yayin No:4569946

Bayraktaroglu, S. (2014). Taekwondocularin psikolojik saglamlik ve oz-anlayis duzeylerinin takim sporculariyla karsilastirilmasi, Yayinlanmamis Yuksek Lisans Tezi, Mugla Sitki Kocman Universitesi, Mugla.

Berry, J. W., \& Worthington, E. L., (2001). Forgivingness, Relationship Quality, Stress While Imagining Relationship Events, and Physical and Mental Health. Journal of Counseling Psychology, 48, 447-455. https://doi.org/10.1037/0022-0167.48.4.447

Berry, J. W., Worthington, E. L., O'Connor, L. E., Parrot, L., \& Wade, N. G. (2005). Forgiveness, Vengeful Rumination, and Affective Traits. Journal of Personality, 73(1), 183-226. https://doi.org/10.1111/j.1467-6494.2004.00308.x

Bezmez, S., Blakney, R., \& Brown, C. H. (1999). English-Turkish / Turkish-English- Redhouse Dictionary. Istanbul: Sev Publisher (Redhouse)

Block, J., \& Kremen, A. M. (1996). IQ and Ego-Resiliency: Conceptual and Empirical Connections and Separateness. Journal of Personality and Social Psychology, 70(2), 349-361. https://doi.org/10.1037/0022-3514.70.2.349

Capan, A., \& Aricioglu, A. (2014). Psikolojik Saglamligin Yordayicisi Olarak Affedicilik. International Journal of Educational Research, 5(4), 70-82.

Dogan, T. (2015). Kisa Psikolojik Saglamlik Olcegi'nin Turkce Uyarlamasi: Gecerlik ve Guvenirlik Calismasi. The Journal of Happiness \& Well-Being, 3(1), 93-102.

Droll, D. M. (1984). Forgiveness: Theory and Research. Unpublished doctoral dissertation, University of Nevada, Reno.

Enright, R. D., \& Gassin, E. A. (1992). Forgiveness: A Developmental View. Journal of Moral Education, 21, 99-114. https://doi.org/10.1080/0305724920210202

Eryilmaz, S. (2012). Universite Ogrencilerinde Psikolojik Saglamligi Yordamada, Yasam Doyumu, Benlik Saygisi, Iyimserlik ve Kontrol Odaginin Incelenmesi. Yayimlanmamis Yuksek Lisans Tezi, Mugla Universitesi, Egitim Bilimleri Enstitusu.

Guloglu, B., \& Karairmak, O. (2010). Universite Ogrencilerinde Yalnizligin Yordayicisi Olarak Benlik Saygisi ve Psikolojik Saglamlik. Ege Egitim Dergisi, 11(2), 73-88.

Gurgan, U. (2006). Grupla Psikolojik Danismanin Universite Ogrencilerinin Yilmazlik Duzeyine Etkisi. Yayimlanmamis doktora tezi, Ankara Universitesi, Egitim Bilimleri Enstitusu.

Hargrave, T. D., \& Sells, J. N. (1997). The Development of A Forgiveness Scale. Journal of Marital and Family Therapy, 23, 41-62. https://doi.org/10.1111/j.1752-0606.1997.tb00230.x

Hee-Kyung, K., \& Mihyoung, L. (2014). Effectiveness of Forgiveness Therapy on Resilience, Self-Esteem, and Spirituality of Wives of Alcoholics. Korean Society of Nursing Science, 44(3), 237-247.

Kararirmak, O. (2006). Psikolojik Saglamlik, Risk Faktorleri ve Koruyucu Faktorler. Turk Psikolojik Danisma ve Rehberlik Dergisi, 3(26), 129-138.

Karasar, N. (2010). Bilimsel Arastirma Yontemi, Kavramlar, Ilkeler, Teknikler. (Yirmi birinci baski) Istanbul: Nobel Yayin Dagitim.

Kaya, F. (2015). Universite Ogrencilerinin Affetme ve Mukemmeliyetcilik Duzeyleri Arasindaki Iliski: Duygusal Zekânin Araci Rolu. Yayimlanmamis Yuksek Lisans Tezi, Ataturk Universitesi, Egitim Bilimleri Enstitusu.

Luthar, S. S., \& Cichetti, D. (2000). The Construct of Resilience: Implications for Interventions and Social Policies. Development and Psychopathology, 12, 857-885. https://doi.org/10.1017/S0954579400004156

Masten, A. S. (2014). Ordinary magic-resilience in development. New York: The Guilford Press.

McCullough, M. E., Pargament, C., \& Thoresen, E. (2001). Forgiveness: Theory, Research and Practice (s.17-40). New York: Guilford Press.

McCullough, M. E., Root, L. M., Tabak, B., \& Witvliet, C. V. O. (2009). Forgiveness. In S. J. Lopez (Ed.), Handbook of Positive Psychology (pp. 427-435). New York: Oxford.

Mumcu, E. H., Acet, M., Kusan, O., Zambak, O., \& Koc, C. M. (2017). Examining to see elite sight- disabled athletes according to the dimensions of the scale of motivation in sport. International Journal of Human Sciences, 14(3), 2590-2591. https://doi.org/10.14687/jhs.v14i3.4395

Murphy, J. G., \& Hampton, J. (1988). Forgiveness and mercy. Cambridge University Press. 
https://doi.org/10.1017/CBO9780511625121

Orathinkal, J., Vanteenwegen, A., \& Buruggrave, R. (2008). Are Deographics Important for Forgiveness. The Family Journal, 16(20), 20-27. https://doi.org/10.1177/1066480707309542

Ogulmus, S. (29-30 Mart 2001). Bir Kisilik Ozelligi Olarak Yilmazlik. 1. Ulusal Cocuk ve Suc Sempozyumu: Nedenler ve Onleme Calismalari, Ankara.

Ozkara, A. B. (2019). Spor Lisesi Ogrencilerinin Girisimcilik Yeterliliklerinin Incelenmesi, Manas Sosyal Arastirmalar Dergisi, 8(1/2), 1339-1347.

Pietrzak, R. H., Johnson, D. C., Goldstein, M. B., Malley, J. C., \& Southwick, S. M. (2009). Psychological Resilience and Postdeployment Social Support Protect Against Traumatic Stres and Depressive Symptoms in Soldiers Returning from Operations Enduring Freedom and Iraqi Freedom. Journal of Special Operations Medicine, 9(3), 67-73.

Rutter, M. (1985). Resilience in the face of adversity: Protective factors and resistance to psychiatric disorder. British Journal of Psychiatry, 147, 598-611. https://doi.org/10.1192/bjp.147.6.598

Rye, M. S., Pargament, K. I., Ali, M. A., Beck, G. L., Dorff, E. N., ... Williams, J. G. (2000). Religious Perspectives on Forgiveness. In M. E. McCllough, K. I. Pargament, C. E. Thoresen (Eds.), Forgiveness: Theory, Research and Practice (s.17-40). New York: Guilford.

Seligman, M., \& Csikzentmihalyi, M. (2000). Positive Psychology: An Introdaction. American Psychologist, 55, 5-14. https://doi.org/10.1037/0003-066X.55.1.5

Sheffield, C. J. (2003). An Investigation of Relationships Between Forgiveness, Religiosity, Religious Coping, and Psychological Well-Being. Unpublished Doctoral Dissertation. Brigham Young University, USA.

Smith, B. W., Dalen, J., Wiggins, K., Tooley, E., Christopher, P., \& Jennifer, B. J. (2008). The brief resilience scale: Assessing the ability to bounce back. International Journal of Behavioral Medicine, 15, 194-200. https://doi.org/10.1080/10705500802222972

Sahin, D. (2014). Ogretmelerin oz duyarliklarinin psikolojik saglamlik ve yasam doyumu acisindan incelenmesi. Yayinlanmamis Yuksek Lisans Tezi. Karadeniz Teknik Universitesi, Trabzon.

Terzi, S. (2005). Oznel Iyi Olmaya Iliskin Psikolojik Dayaniklilik Modeli. Yayimlanmamis Doktora Tezi, Gazi Universitesi, Egitim Bilimleri Enstitusu.

Toprak, H. (2014). Ergenlerde Mutluluk ve Yasam Doyumunun Yordayicisi Olarak Psikolojik Saglamlik ve Psikolojik Ihtiyac Doyumu. Yayimlanmamis Yuksek Lisans Tezi, Sakarya Universitesi, Egitim Bilimleri Enstitusu.

Turgut, O. (2015). Ergenlerin Psikolojik Saglamlik Duzeylerinin, Onemli Yasam Olaylari, Algilanan Sosyal Destek Ve Okul Bagliligi Acisindan İncelenmesi, Yayinlanmamis Yuksek Lisans Tezi, Anadolu Universitesi, Eskisehir, 2015.

Tusaire, K., \& Dyer, J. (2004). Resilience: A Historical Review of the Construct. Holist Nurs Pract, 18, 3-8. https://doi.org/10.1097/00004650-200401000-00002

Yesilyaprak, B. (2002). Universiteye Devam Eden ve Etmeyen Bir Grup Gencin Psikolojik Belirtiler Acisindan Karsilastirilmasi. Turk Psikolojik Danisma ve Rehberlik Dergisi, 18, 35-42.

Wagnild, G. M., \& Young, H. M. (1993). Development and Psychometric Evaluation of the Resilience Scale. Journal of Nursing Measurement, 1, 165-178.

Werner, E. E. (1995). Resilience in Development. Current Direction In Pychological Science, 4, 81-85. https://doi.org/10.1111/1467-8721.ep10772327

Worthington, E. L. (1997). The Pyramid Model of Forgiveness. In Worthington E.L. (Eds.), Dimensions of Forgiveness: Psychological Research and Theoretical Perspective. Philade: Templetion Foundation Press.

Akin, A., Akin, U., \& Gediksiz, E. (3-5 Mayis 2012). The Valitiy and Reliability of the Turkish Version of the Forgivingness Scale. International Counseling and Education Conference 2012. Lutfi Kirdar Kongre Merkezi, Istanbul.

\section{Copyrights}

Copyright for this article is retained by the author(s), with first publication rights granted to the journal.

This is an open-access article distributed under the terms and conditions of the Creative Commons Attribution license which permits unrestricted use, distribution, and reproduction in any medium, provided the original work is properly cited. 